\title{
A Chemical Transport Model Emulator for the Interactive Evaluation of Mercury Emission Reduction Scenarios
}

\author{
Francesco De Simone ${ }^{1, *(\mathbb{D}}$, Francesco $\mathrm{D}^{\prime}$ Amore ${ }^{1}\left(\mathbb{D}\right.$, Francesco Marasco $^{2}$, Francesco Carbone ${ }^{1}$, \\ Mariantonia Bencardino ${ }^{1}$, Ian M. Hedgecock ${ }^{1}{ }^{(\mathbb{D}}$, Sergio Cinnirella ${ }^{1}{ }^{\circledR}$, Francesca Sprovieri ${ }^{1}$ \\ and Nicola Pirrone ${ }^{1}$ \\ 1 CNR-Institute of Atmospheric Pollution Research, Division of Rende, UNICAL Polifuzionale, \\ 87036 Rende (CS), Italy; damore@iia.cnr.it (F.D.); carbone@iia.cnr.it (F.C.); bencardino@iia.cnr.it (M.B.); \\ hedgecock@iia.cnr.it (I.M.H.); cinnirella@iia.cnr.it (S.C.); sprovieri@iia.cnr.it (F.S.); pirrone@iia.cnr.it (N.P.) \\ 2 Independent Researcher, via Picardi, 87100 Cosenza (CS), Italy; fmarasco@gmail.com \\ * Correspondence: francesco.desimone@iia.cnr.it
}

Received: 20 July 2020; Accepted: 12 August 2020; Published: 18 August 2020

\begin{abstract}
Implementation of the Minamata Convention on Mercury requires all parties to "control, and where feasible, reduce" mercury $(\mathrm{Hg})$ emissions from a convention-specified set of sources. However, the convention does not specify the extent of the measures to be adopted, which may only be analysed by decision-makers using modelled scenarios. Currently, the numerical models available to study the $\mathrm{Hg}$ atmospheric cycle require significant expertise and high-end hardware, with results which are generally available on a time frame of days to weeks. In this work we present HERMES, a statistical emulator built on the output of a global Chemical Transport Model (CTM) for $\mathrm{Hg}$ (ECHMERIT), to simulate changes in anthropogenic $\mathrm{Hg}\left(\mathrm{Hg}_{\text {anthr }}\right)$ deposition fluxes in a source-receptor framework, due to perturbations to $\mathrm{Hg}_{\text {anthr }}$ emissions and the associated statistical significance of the changes. The HERMES emulator enables stakeholders to evaluate the implementation of different $\mathrm{Hg}_{\mathrm{anthr}}$ emission scenarios in an interactive and real-time manner, simulating the application of the different Best Available Technologies. HERMES provides the scientific soundness of a full CTM numerical framework in an interactive and user-friendly spreadsheet, without the necessity for specific training or formation and is a first step towards a more comprehensive, and integrated, decision support system to aid decision-makers in the implementation of the Minamata Convention.
\end{abstract}

Keywords: mercury; CTM emulator; decision support system; emission control; emission reduction; minamata convention

\section{Introduction}

Mercury $(\mathrm{Hg})$ is a global pollutant since it impacts regions and ecosystems which are far from emission sources, due to its long range atmospheric transport [1]. The Minamata Convention on Mercury (MCM) (http://www.mercuryconvention.org/) was established to reduce mercury contamination resulting from anthropogenic activities. However, no specifications were set within the convention regarding policy and technical aspects, specific emission limits, reduction targets, or the specific control technologies to be applied [2,3].

Thus, each of the countries involved will apply their own measures unilaterally. However, it is clear that $\mathrm{Hg}$ pollution is a global concern, and a number of studies indicate that a coordinated set of actions is required for $\mathrm{Hg}$ emission control to be effective, due to the large uncertainties regarding the 
processes that determine the global atmospheric cycle of $\mathrm{Hg}$, and thus in establishing Source-Receptor (SR) relationships [4-6].

Selin [3], following the metric-based approach used in the context of the Montreal Protocol, to reduce halogens in the stratosphere [7], developed a metric that could be useful for policies focusing on the reduction of $\mathrm{Hg}$ pollution under the MCM.

The metric, however, as recognised by the authors, suffers from limitations since it was designed to capture the anthropogenic $\mathrm{Hg}$, (hereafter $\mathrm{Hg}_{\mathrm{anthr}}$ ), contribution to global deposition, and therefore does not support any strategic policies focusing on reducing $\mathrm{Hg}_{\text {anthr }}$ deposition in a particular nation or region. It was also not designed to account directly for the emission speciation of $\mathrm{Hg}_{\text {anthr }}$, which influences the fraction of $\mathrm{Hg}_{\text {anthr }}$ that deposits locally and/or regionally. This is a major limitation within the scope of current emission reduction strategies. Indeed, each of the Best Available Technologies (BATs) and Best Environmental Practices (BEPs) to be considered for reducing $\mathrm{Hg}_{\text {anthr }}$ emissions will result in a change of emission speciation [8], and therefore on the ratio of local to nonlocal $\mathrm{Hg}_{\text {anthr }}$ deposition. Furthermore, it does not provide information concerning the statistical significance of the outcome of any given reduction approach, which is necessary when facing the significant degree of uncertainty in modelling the processes related to $\mathrm{Hg}$ cycle in the different ecosystem compartments [4,5,9-12].

It is worth noting that the only available tools capable of tracking the fate of $\mathrm{Hg}_{\text {anthr }}$ from emission source to deposition receptor are Chemical Transport Models (CTMs) developed specifically to study the atmospheric cycle of $\mathrm{Hg}$. Unfortunately, these complex numerical models require suitable expertise, specific training, and dedicated hardware to run. Even if packaged to be as user-friendly as possible, each run could require from hours to days for its entire workflow (design, initialisation, run, and results collection, analysis, and visualisation) to be completed, making them far from interactive, and unlikely to be used directly by policy-makers. Furthermore, a significant number of runs are required to provide statistically robust results. Clearly a simpler approach, directly accessible to policy-makers is required, to aid understanding and assessment of the $\mathrm{Hg}$ cycle and the implications of the policy options available. HERMES is an emulator built on an appropriate set of outputs obtained from the state-of-the-art Hg-CTM ECHMERIT [13,14].

Emulators are often used to simulate complex phenomena like climate change, (see, for example, Holden et al. [15], Castruccio et al. [16]) that permit the investigation of the forcing of arbitrary $\mathrm{CO}_{2}$ concentrations on climate variables of interest at a computational cost that is many orders of magnitude lower than that required by a conventional climate model. Recent studies have applied the same basic principle to predict the response of $\mathrm{O}_{3}$ and $\mathrm{PM}_{2.5}$ concentrations to precursor emissions $[17,18]$. Other studies offer different statistical approaches used to increase the information from a limited set of model runs to investigate the uncertainty within processes simulated by conventional CTMs (see for example Beddows et al. [19]). However, none of these have been applied to the analysis of $\mathrm{Hg}$ pollution.

The output from HERMES allows the evaluation of the short-term (nominally one-year) effects on $\mathrm{Hg}_{\text {anthr }}$ deposition fluxes due to $\mathrm{Hg}_{\text {anthr }}$ emission perturbation. To cover a wide range of scenarios, in this work perturbations cover both emission reduction percentage and speciation, simulating the effect and the benefits of the BATs available to policy-makers for reducing $\mathrm{Hg}_{\text {anthr }}$ emissions, within a source-receptor framework [4].

With HERMES, a nonexpert user can perturb the $\mathrm{Hg}_{\text {anthr }}$ emissions in up to 15 source regions worldwide and can observe, in real-time, the effects on 21 receptor regions, and in particular with an indication of the statistical significance of the perturbation effects, relative to coefficient intervals of deposition as calculated in the current situation [4]. This aspect is of particular importance since it is necessary for researchers moving forward to increase transparency in order to inform policy makers of the limitations and uncertainties of the models used [20]. 
This approach overcomes the major issues identified in the prior state-of-the-art, allowing the evaluation of a number of emission reduction policy scenarios at the level of a specified region/country, as demonstrated in the following sections.

\section{Materials and Methods}

The basic idea behind the development of a CTM emulator is to run a number of anthropogenic emission control scenarios (the "Scenario experiments" below) and to analyse the response of the system in order to find a predictable pattern $[17,18]$. If such a pattern exists, it can be used to simulate the response of the system for all other possible emission scenarios, thus saving time and computational costs, within errors which magnitudes clearly depend on the goodness of fitting model used to approximate the response function.

\subsection{Simulation of the $\mathrm{Hg}_{\text {anthr }}$ Atmospheric Cycle}

The simulation of the atmospheric cycle of $\mathrm{Hg}_{\text {anthr }}$ was performed using the global $\mathrm{Hg}$-CTM model ECHMERIT [13,14].

Two sets of experiments were conducted, where $\mathrm{Hg}_{\text {anthr }}$ emissions were tagged according to their source region, as reported in the HTAPv2 experiment (http:/ /www.htap.org/) (see Figure 1), to allow the source apportionment of the subsequent $\mathrm{Hg}_{\text {anthr }}$ deposition. The $\mathrm{Hg}_{\text {anthr }}$ emissions were included in the model from three different anthropogenic inventories, referred to here as AMAP [21], EDGAR [22], and STREETS [23,24].

Firstly, the emission fields were mapped to the HTAPv2 mask at their original resolution using the large fraction area method, they were then interpolated onto the ECHMERIT T42 horizontal grid (roughly $2.8^{\circ}$ by $2.8^{\circ}$ at the equator) using the mass conserving remapping method; both methods are available in the Climate Data Operators (CDO) [25] package. Finally, the emissions were distributed vertically (up to $10 \mathrm{hPa}$ ), at run time, using the relevant prescribed height distribution, mapping them to Standardized Nomenclature for Air Pollutants (SNAP) and using the distribution in Simpson et al. [26] or evenly injecting them within the Planetary Boundary Layer (PBL) (see De Simone et al. [10] for details).

A spin-up period of 4 years was employed for both sets of runs, and the results from the fifth year, namely 2010, were then considered for the analysis.

A BASE run is shared by both sets of experiments and includes an $\mathrm{Hg}$ oxidation mechanism driven by $\mathrm{O}_{3} / \mathrm{OH}$ fields, imported from the Mozart model [27], and $\mathrm{Hg}_{\text {anthr }}$ emissions from $\mathrm{AMAP} / \mathrm{UNEP}[21]$.

The first set of experiments, the "Characterising experiments", aims only to define and characterise the $\mathrm{Hg}_{\mathrm{anthr}}$ atmospheric cycle to provide robust constraints of confidence intervals of the contributions to deposition in each receptor region. To this aim, a number of parameters, model assumptions, and inventories were varied, covering a reasonable range of uncertainties known to influence the $\mathrm{Hg}$ atmospheric cycle. All these runs, although leading to changes in $\mathrm{Hg}$ surface concentration and deposition fields, were demonstrated to be statistically indistinguishable between each other when compared with the available field measurements, as described in [10].

A number of runs were conducted employing different $\mathrm{Hg}_{\text {anthr }}$ emission height distributions (APBL), as well as different $\mathrm{Hg}_{\text {anthr }}$ speciation ratios, only as $\mathrm{Hg}_{(\mathrm{g})}^{0}(\mathrm{NSP} 0)$, or emitted at a ratio $\mathrm{Hg}_{(\mathrm{g})}^{0}: \mathrm{Hg}_{(\mathrm{g} / \mathrm{p})}^{\mathrm{II}} 50 / 50$ (NSP50).

Years with different meteorological characteristics were also simulated to evaluate the effects of changing atmospheric transport conditions, (BASE-2005 and BASE-1998). They were selected according to opposite values of major climatic indices which result in different circulation and precipitation patterns $[28,29]$. 

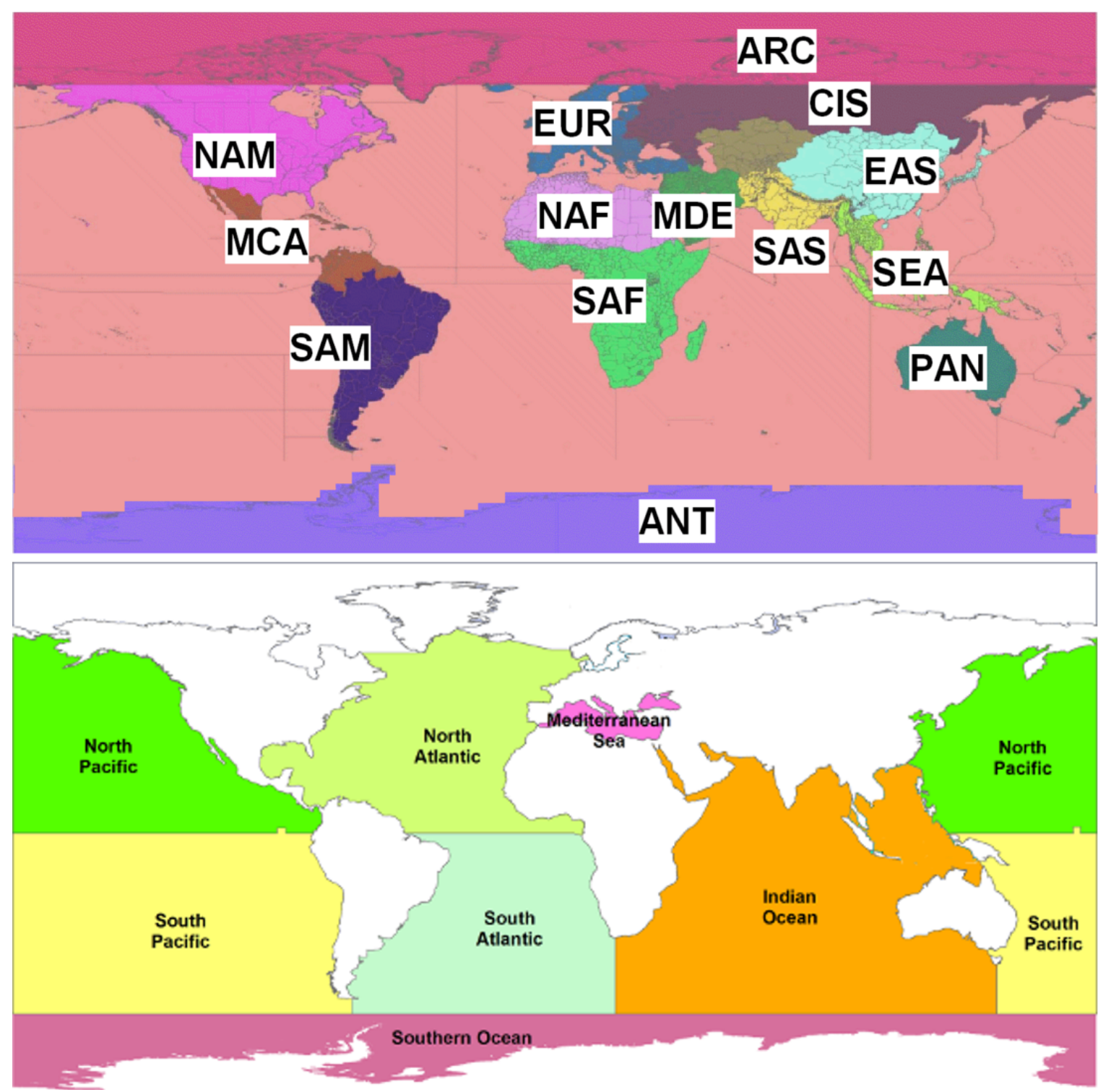

Figure 1. Upper panel: definition of the source regions used herein. NAM (North America), EUR (Europe), SAS (South Asia), EAS (East Asia), SEA (South East Asia), PAN (Australia), NAF (North Equatorial Africa), SAF (South Equatorial Africa), MDE (Middle East Asia), MCA (Central America), SAM (South America), CIS (Central Asia), ARC (Arctic, above $66^{\circ} \mathrm{N}$ ). Lower panel: Definition of the ocean basins used here. Note that Southern Ocean and ANT are, respectively, the ocean and the Antarctic continent below $60^{\circ} \mathrm{S}$.

Due to uncertainties of the atmospheric $\mathrm{Hg}$ oxidation pathway [30-32], a run was performed considering an oxidation mechanism based on Bromine (BRTO) (from p-Tomcat [33,34]).

Finally, two runs including, respectively, EDGAR and STREETS inventories were run to explicitly account for the uncertainties regarding $\mathrm{Hg}_{\text {anthr }}$ emissions.

A summary of the runs performed within the scope of the Characterising experiments is reported in Table 1 below. 
Table 1. "Characterising experiments" that computed the $\mathrm{Hg}_{\text {anthr }}$ deposition in each receptor region.

\begin{tabular}{|c|c|c|c|c|c|c|}
\hline Run & Inventory & Ref. Year & Meteor. Year & Speciation & Vertical Profile & Oxidation \\
\hline BASE & AMAP-2010 & 2010 & 2010 & Native & Native & $\mathrm{O}_{3}+\mathrm{OH}$ \\
\hline BASE-2005 & AMAP-2010 & 2010 & 2005 & Native & Native & $\mathrm{O}_{3}+\mathrm{OH}$ \\
\hline BASE-1998 & AMAP-2010 & 2010 & 1998 & Native & Native & $\mathrm{O}_{3}+\mathrm{OH}$ \\
\hline APBL & AMAP-2010 & 2010 & 2010 & Native & Uniform PBL & $\mathrm{O}_{3}+\mathrm{OH}$ \\
\hline NSP0 & AMAP-2010 & 2010 & 2010 & as $\mathrm{Hg}_{(\mathrm{g})}^{0}$ & Native & $\mathrm{O}_{3}+\mathrm{OH}$ \\
\hline NSP50 & AMAP-2010 & 2010 & 2010 & $\mathrm{Hg}_{(\mathrm{g})}^{0}: \mathrm{Hg}_{(\mathrm{g})}^{\mathrm{II}}=50: 50$ & Native & $\mathrm{O}_{3}+\mathrm{OH}$ \\
\hline BRTO & AMAP-2010 & 2010 & 2010 & Native & Native & Bromine \\
\hline STREETS & STREETS & 2010 & 2010 & Native & Uniform PBL & $\mathrm{O}_{3}+\mathrm{OH}$ \\
\hline EDGAR & EDGAR & 2010 & 2010 & Native & Native-SNAP & $\mathrm{O}_{3}+\mathrm{OH}$ \\
\hline
\end{tabular}

A bootstrap analysis [35] was then used to evaluate the average $\mathrm{Hg}_{\text {anthr }}$ deposition in each receptor region due to each source region and to determine the relative confidence intervals, following the procedure described in De Simone et al. [4].

The second set of experiments, defined as "Scenario experiments", represents the core of the present study. The runs belonging to this set were performed using only the AMAP/UNEP [21] emission inventory, since for the scope of this study we want to simulate the response of $\mathrm{Hg}_{\text {anthr }}$ deposition to $\mathrm{Hg}_{\text {anthr }}$ emission perturbations using this inventory.

To simplify the emission control simulations, we assumed a decrease of the number of $\mathrm{Hg}_{\text {anthr }}$ species emitted. Gaseous elemental mercury $\left(\mathrm{Hg}_{(\mathrm{g})}^{0}\right)$ and reactive mercury $\left(\mathrm{Hg}^{\mathrm{R}}\right)$ were taken into account. The latter as a lumped species representing oxidised mercury $\left(\mathrm{Hg}_{(\mathrm{g})}^{2}\right)$ and particle bounded mercury $\mathrm{Hg}_{(\mathrm{p})}$, both considered to be emitted with a constant ratio as in AMAP/UNEP [21]. Reduction changes were simulated (BaseR20 to BaseR80), as were different ratios of $\mathrm{Hg}_{(\mathrm{g})}^{0}: \mathrm{Hg}^{\mathrm{R}}$ (BaseS00 to BaseS100), leaving all other model parameters and assumptions equal to those in the BASE run. The runs of Scenario experiments, listed in Table 2, were used to build the HERMES emulator, as described in the following Section 2.2.

Table 2. List of Scenario experiments conducted with a common emission database (AMAP [21]) and reducing the emissions (BaseR20 to BaseR80) as well as changing the speciation ratio (BaseS00 to BaseS100).

\begin{tabular}{cccc}
\hline Run & Emissions & HgR:Hg0 & Reduction \\
\hline BASE & AMAP & Original & None \\
BaseR20 & AMAP & Original & $20 \%$ \\
BaseR40 & AMAP & Original & $40 \%$ \\
BaseR60 & AMAP & Original & $60 \%$ \\
BaseR80 & AMAP & Original & $80 \%$ \\
BaseS00 & AMAP & $0: 100$ & None \\
BaseS20 & AMAP & $20: 80$ & None \\
BaseS40 & AMAP & $40: 60$ & None \\
BaseS60 & AMAP & $60: 40$ & None \\
BaseS80 & AMAP & $80: 60$ & None \\
BaseS100 & AMAP & $100: 0$ & None \\
\hline
\end{tabular}

\subsection{Building the HERMES Emulator}

The scope of this study is to provide a CTM emulator, HERMES, to calculate new $\mathrm{Hg}_{\text {anthr }}$ deposition fluxes for each receptor related to $\mathrm{Hg}_{\text {anthr }}$ emission perturbation(s) in one or more source regions. The characteristics of the $\mathrm{Hg}_{\text {anthr }}$ emission amount and speciation ratio, can be controlled, thus simulating the adoption of available abatement techniques. The HERMES emulator output is a new $\mathrm{Hg}_{\text {anthr }}$ deposition value for each receptor. To achieve this, the deposition fields resulting from the Scenario experiment ECHMERIT runs were fitted using the best model available. 
Since $\mathrm{Hg}$ in the CTM model is due only to the anthropogenic emissions (i.e., $\mathrm{Hg}_{\text {anthr }}$ species are neither created nor destroyed within the model), the deposition in the model domain cells resulting from $\mathrm{Hg}_{\text {anthr }}$ emission reduction (runs BaseR20 to BaseR80) is directly proportional to the reduction (adjusted $R^{2} \sim 1$ ). Therefore, the $\mathrm{Hg}_{\text {anthr }}$ deposition in the receptor region $r$ due to the emission reduction in the source region $s$, namely $D E P_{r, s}^{\text {Red }}$, is calculated by HERMES as follows

$$
D E P_{r, s}^{\text {Red }}=\left(100-I N P U T_{s}^{\text {Red }}\right) * D E P_{r, s}^{B A S E}
$$

where $I N P U T_{s}^{R e d}$ is the $\mathrm{Hg}_{\text {anthr }}$ emission reduction in the source region $s$ as a percentage $(0-100 \%)$, and $D E P_{r, s}^{B A S E}$ is the $\mathrm{Hg}_{\text {anthr }}$ deposition, in the receptor region $r$ due to the source region $s$, in the unperturbed scenario (BASE run).

A linear model is also sufficient (adjusted $R^{2} \sim 1$ ) to describe the $\mathrm{Hg}_{\text {anthr }}$ deposition resulting from emission speciation perturbation runs(BaseS00 to BaseS100) and $\mathrm{Hg}_{\mathrm{anthr}}$ deposition in the receptor region $r$ due to the emission speciation perturbation in the source region $s, D E P_{r, s}^{S p e c}$, is,

$$
D E P_{r, s}^{S p e c}=A_{s, r}^{S p e c}+I N P U T_{s}^{S p e c} * B_{s, r}^{S p e c}
$$

where INPUT $T_{S}^{\text {Spec }}$ represents the ratio between $\mathrm{Hg}_{(\mathrm{g})}^{0}(0=100 \%)$ and $\mathrm{Hg}^{\mathrm{R}}(1=100 \%) ; A_{s, r}^{\text {Spec }}$ and $B_{s, r}^{\text {Spec }}$ are the coefficients of the linear equation and represent the deposition of $\mathrm{Hg}_{\text {anthr }}$ in the receptor region $r$ due to the emission in source region $s$ in the case where $\mathrm{Hg}_{\text {anthr }}$ is totally gaseous and the rate at which the deposition changes as the contribution of reactive mercury increases.

From relation (1) between $D E P_{r, s}^{\text {Red }}$ and $I N P U T_{s}^{\text {Red }}$, the following polynomial can be derived relating the deposition $D E P_{r, s}^{H E R M E S}$, in the receptor region $r$ due to the change of $\mathrm{Hg}_{\text {anthr }}$ in both terms of emission reduction $\left(I N P U T_{S}^{R e c}\right)$, and speciation $\left(I N P U T_{S}^{S p e c}\right)$ in the source region $s$ :

$$
D E P_{r, s}^{H E R M E S}=A_{s, r}^{\text {Spec }} *\left(100-\operatorname{INPUT}_{s}^{\text {Red }}\right)+\operatorname{INPUT}_{s}^{\text {Spec }} * B_{s, r}^{\text {Spec }} *\left(100-\operatorname{INPUT}_{s}^{\text {Red }}\right)
$$

with all variables as defined above.

Equation (3) represents the core of the of HERMES emulator, and for ease of use it is implemented in a spreadsheet file available in the Supporting Information.

The new deposition value, $D E P_{r, s}$, is finally compared to the relative bounds at $95 \%$ confidence interval (CI) at either tail (see Table 3), with indications if it falls outside the bounds, as further described below.

By the way the experiments were designed, the HERMES emulator calculates the DEP $P_{r, s}^{H E R M E S}$, in the receptor region $r$ due to the perturbation(s) of $\mathrm{Hg}_{\text {anthr }}$ emission in the source region $s$, nominally after one year following the emission perturbation(s).

Moreover, since we included for this analysis only the $\mathrm{Hg}$ emissions from anthropogenic activities, Equations (1) and (2) represent processes that are perfectly linear, as demonstrated by a number of tests regarding the goodness of fit (adjusted $R^{2} \sim 1$, residuals plots and significance of model regression test based on ANOVA at $\alpha=0.01$ ). The equations fit perfectly the response of the $\mathrm{Hg}_{\text {anthr }}$ deposition to control scenarios of $\mathrm{Hg}_{\text {anthr }}$ emissions, in terms of reduction and speciation, respectively, and therefore, they must not be regarded as simple linearisation of the response function.

Since the core Equation (3) is a simple combination of Equations (1) and (2), it means that HERMES can simulate the output of any ECHMERIT runs actually without errors. Indeed, the only differences are negligible, in the order of Kgs, and are just due to the numerical or computational errors in CTM sampling and/or fitting algorithm. 
Table 3. Reference (BASE), and upper and lower bound (95\% level) for the mean of the $\mathrm{Hg}_{\text {anthr }}$ total deposition ( $\mathrm{Mg} /$ year) for each receptor region originating from all source regions.

\begin{tabular}{cccc}
\hline Region & Lower Bound & Reference & Upper Bound \\
\hline North America & 66.87 & 78.41 & 87.96 \\
Australia & 12.86 & 16.08 & 18.97 \\
South East Asia & 117.68 & 146.08 & 182.35 \\
Europe & 30.60 & 37.11 & 43.21 \\
Indonesia & 21.21 & 25.15 & 28.39 \\
Arctic & 32.46 & 35.95 & 38.85 \\
Central America & 20.12 & 23.44 & 26.31 \\
Middle East Asia & 15.42 & 17.65 & 19.35 \\
North Equatorial Africa & 33.61 & 41.56 & 59.13 \\
Central Asia & 69.35 & 79.56 & 89.37 \\
South Equatorial Africa & 74.47 & 89.35 & 101.95 \\
South America & 55.27 & 65.89 & 74.82 \\
South Asia & 34.50 & 45.87 & 57.75 \\
Antarctic & 2.60 & 4.34 & 7.26 \\
\hline Ocean Basins & Lower Bound & Reference & Upper Bound \\
\hline North Atlantic & 143.15 & 159.07 & 168.66 \\
South Atlantic & 90.73 & 109.85 & 125.38 \\
North Pacific & 392.65 & 440.93 & 471.62 \\
South Pacific & 230.59 & 278.56 & 316.00 \\
Indian & 163.22 & 197.70 & 223.76 \\
Mediterranean & 7.87 & 9.05 & 10.33 \\
South Ocean & 8.35 & 11.17 & 15.25 \\
\hline & & &
\end{tabular}

\section{Results}

The outcomes of the Characteristic experiments are summarised in Table 3. It shows, for each of the receptor regions, the reference $\mathrm{Hg}_{\text {anthr }}$ deposition $(\mathrm{Mg} /$ year) due to all of the source regions, as calculated by the BASE run $\left(\sum_{s} D E P_{r}^{B A S E}\right)$. Moreover, it reports the upper and lower bound of the confidence interval (at a 95\% level) of the mean of the $\mathrm{Hg}_{\text {anthr }}$ total deposition ( $\mathrm{Mg} /$ year), due to all the source regions, as estimated by bootstrap.

\subsection{HERMES Case Studies}

Figure 2 illustrates the implementation of HERMES emulator in a spreadsheet and reported in SI.

The upper-left Section (1 in green) shows the input window in which each source region is provided with two sets of sliding bars to change $\mathrm{Hg}_{\text {antrh }}$ emission for each of the source regions. The first slider can reduce the emissions as a percentage, whereas the second allows the selection of the ratio between elemental and reactive $\mathrm{Hg}_{\text {antrh }}$.

The right section of the figure illustrates the output list of receptors, for both terrestrial ( 2 in orange) and oceanic ( 3 in light blue) receptors, each one provided with its reference value, the newly calculated value, and the percentage change of the $\mathrm{Hg}_{\text {antrh }}$ deposition. As explained before, the output is considered nominally one year following $\mathrm{Hg}_{\text {anthr }}$ emission perturbation. Two columns are also reported that are normally blank. The cells eventually become green (or red) if the deposition decrease (or increase) is statistically significant (at a 95\% level of confidence).

A summary reports total deposition over terrestrial and oceanic receptors.

The lower-left Section (4 in yellow) reports in a graphical form the results for terrestrial and oceanic regions. Perturbed deposition fluxes (red bars) are compared against the reference deposition (blue bars) for each receptor.

A reset button returns emission changes to zero (BASE case). 


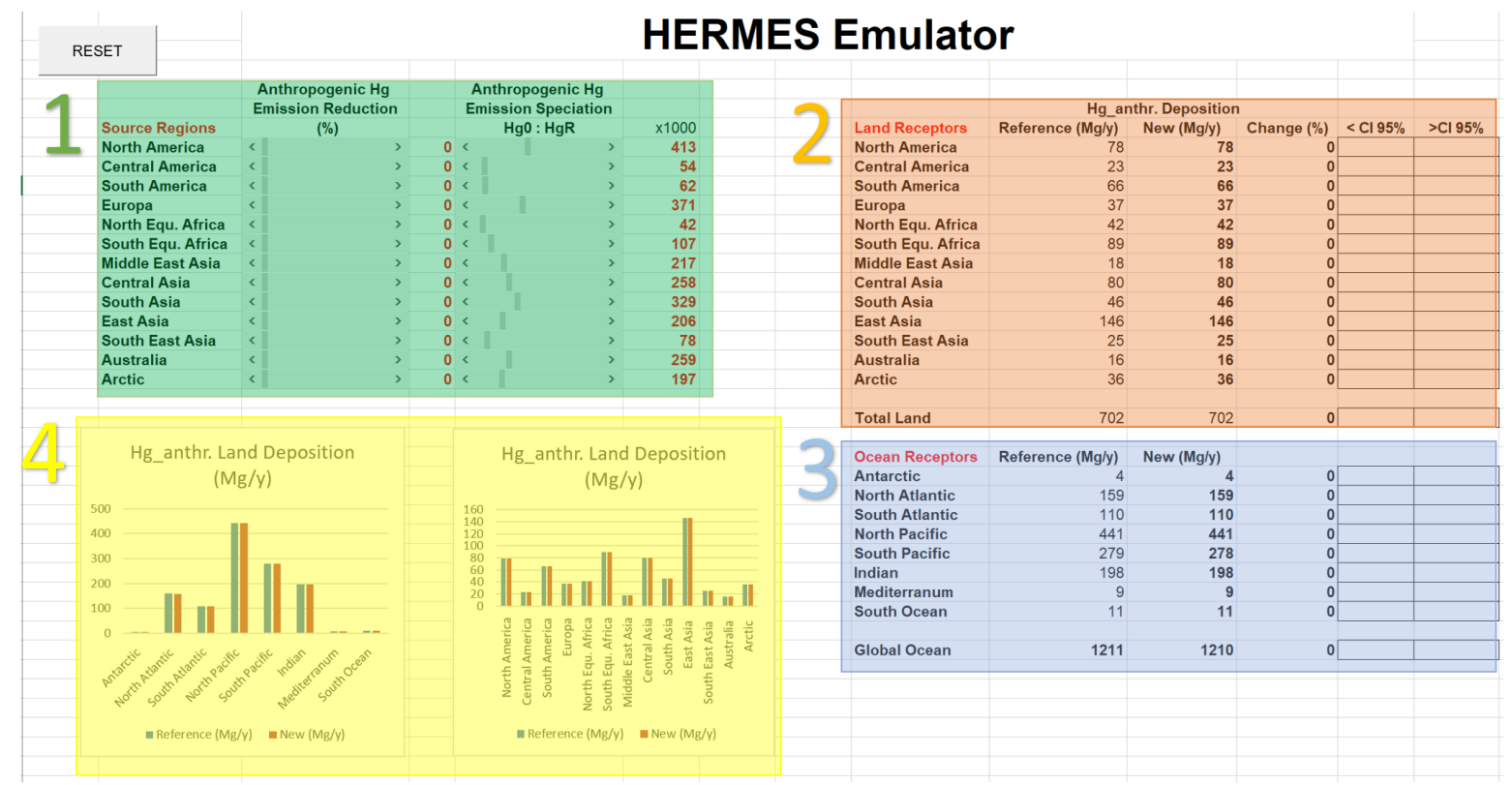

Figure 2. Dashboard interface of HERMES emulator implemented in a spreadsheet with input Section (1, in green), numerical output Sections (2 and 3, orange and light blue), and graphical output Section $(4$, in yellow).

\subsection{Hg Emission Reduction}

To show the potential of HERMES to support decision-makers, a number of case studies are reported hereafter. The first portfolio of cases is related to $\mathrm{Hg}_{\text {anthr }}$ emission reduction.

\subsubsection{Emissions-20\% in all Source Regions}

If we reduce by $20 \%$ the $\mathrm{Hg}_{\text {anthr }}$ emission in all source regions (Figure 3) we see a $20 \%$ reduction of deposition in each receptor. In all receptors the change in deposition is effective (green cells) except for the South Asia, Southern Oceans, and Antarctic, where the uncertainty in the deposition is so high that a $20 \%$ in reduction is not of statistical significance [4].

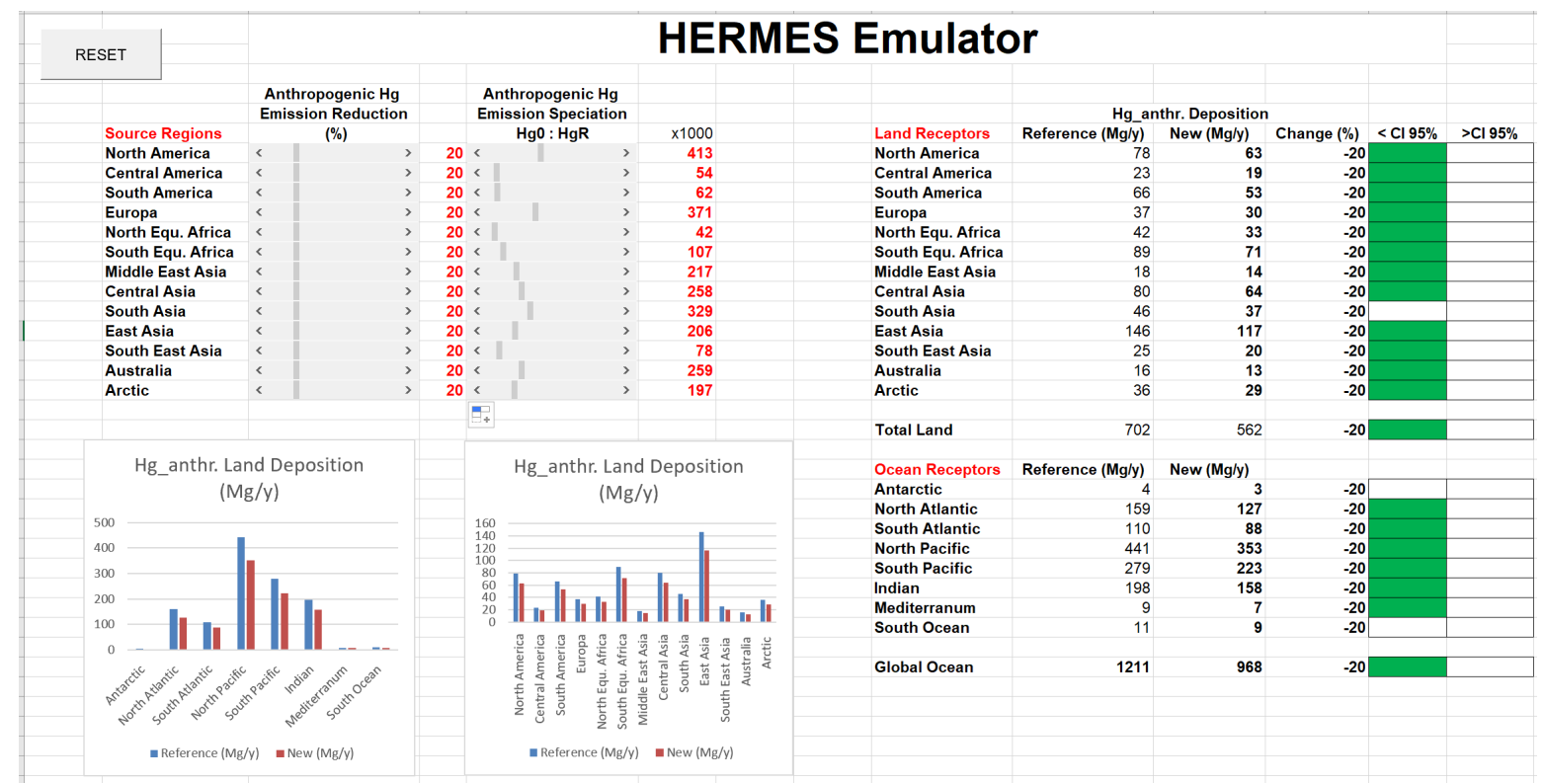

Figure 3. Use-case $1: \mathrm{Hg}_{\text {anthr }}$ emission reduction by $20 \%$ from all source regions. 


\subsubsection{Emissions- $50 \%$ in Key Regions: Europe, East Asia, and North America}

In the next example cases we test the effects of reducing by $50 \%$ the $\mathrm{Hg}_{\text {anthr }}$ emissions in some key source regions to help decision-makers evaluate the extent of eventual measures applied to single countries. When applied to Europe, Figure 4, this measure results in a significant decrease over Europe itself $(-26 \%)$ and the nearby Mediterranean sea $(-17 \%)$, whereas the effects over other receptors, although measurable, are not significant.

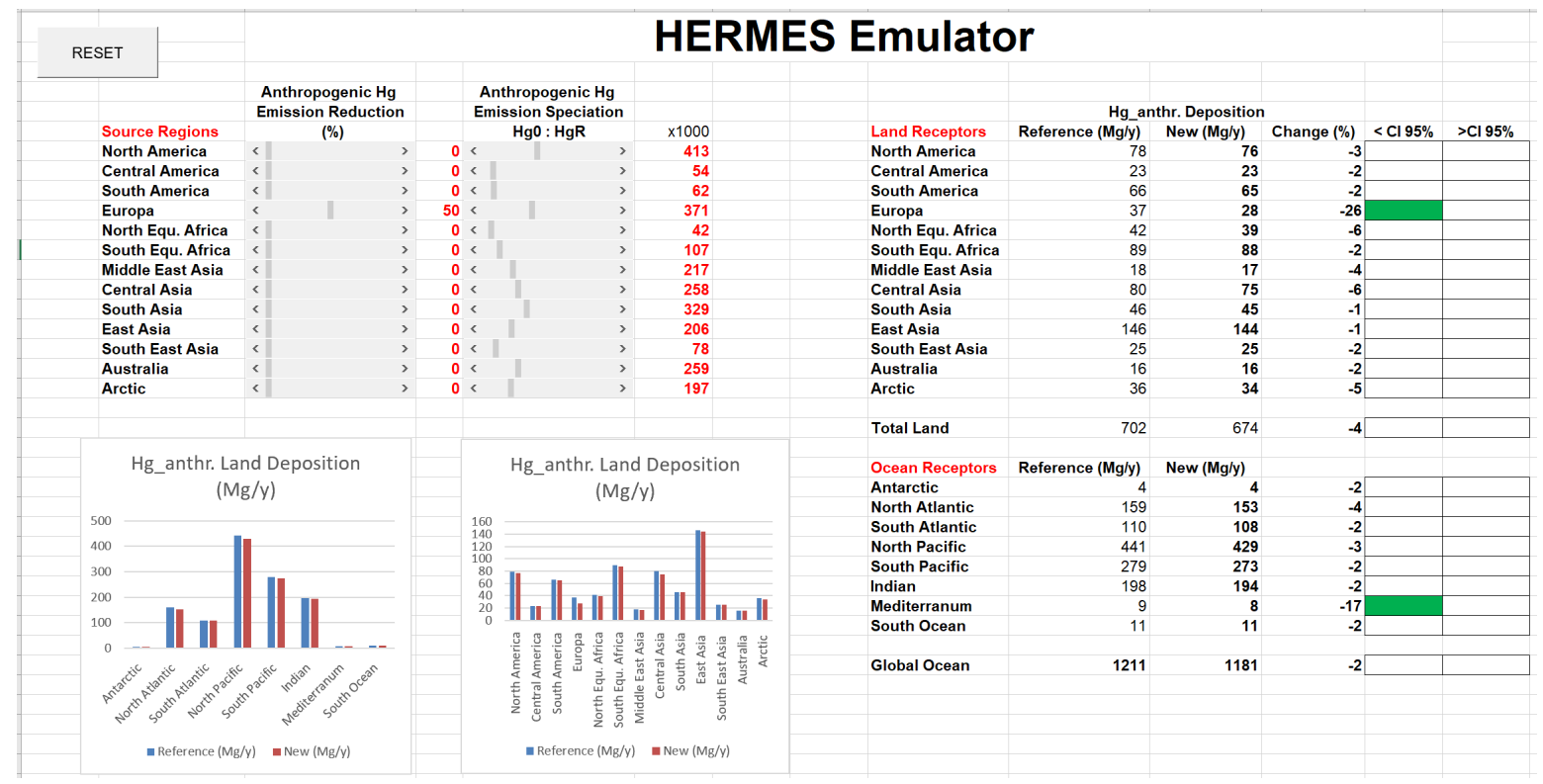

Figure 4. Use-case 2: $\mathrm{Hg}_{\text {anthr }}$ emission reduction by $50 \%$ in Europe.

If we reduce by $50 \%$ the $\mathrm{Hg}_{\text {anthr }}$ emissions in East Asia (Figure 5), there is an evident and significant reduction in a number of regions resulting in an annual deposition decrease over oceans $(16 \%)$ and land $(18 \%)$. Due to the long-range transboundary transport of $\mathrm{Hg}_{\mathrm{anthr}}$, the reduction can impact the Americas, the Arctic, and the whole of Asia as well as the Atlantic Ocean. Reduction of deposition over regions ranges from 35\% for East Asia to about 16\% of Central America, the Middle East, and Central Asia. This measure has a great impact over the oceans of the Norther Hemisphere with a decrease of $\mathrm{Hg}_{\text {anthr }}$ deposition of $18 \%$ for the North Atlantic and $21 \%$ for the North Pacific.

Over other receptors, despite the decrease ranging from $9 \%$ for South Asia to $17 \%$ for North. Eq. Africa, it is not significant.

It is of interest how the reduction of $\mathrm{Hg}_{\text {anthr }}$ emissions by $50 \%$ in North America (Figure 6) has no significant effects in any of the receptor regions. 


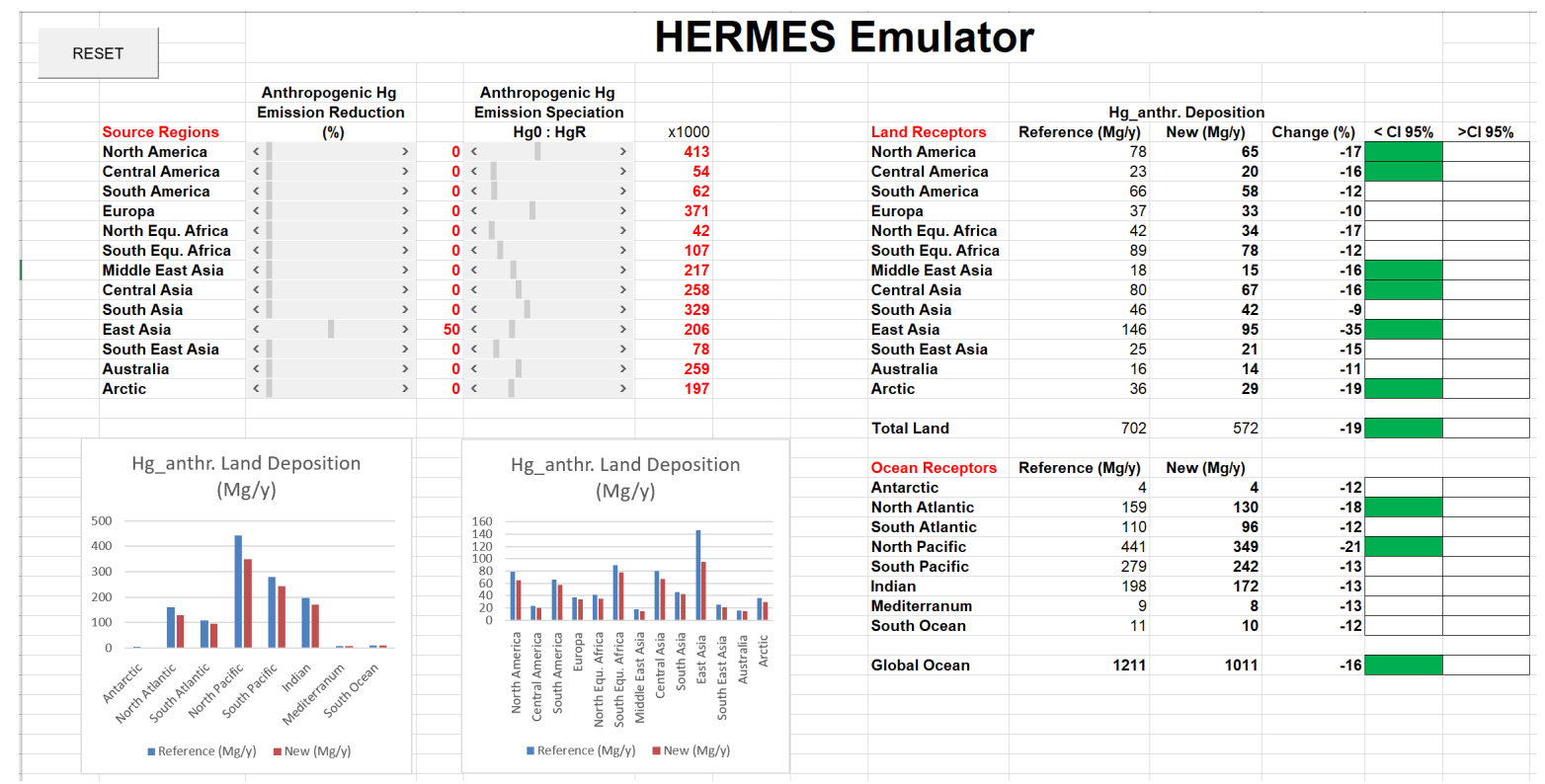

Figure 5. Use-case 3: $\mathrm{Hg}_{\text {anthr }}$ emission reduction by 50\% in East Asia.

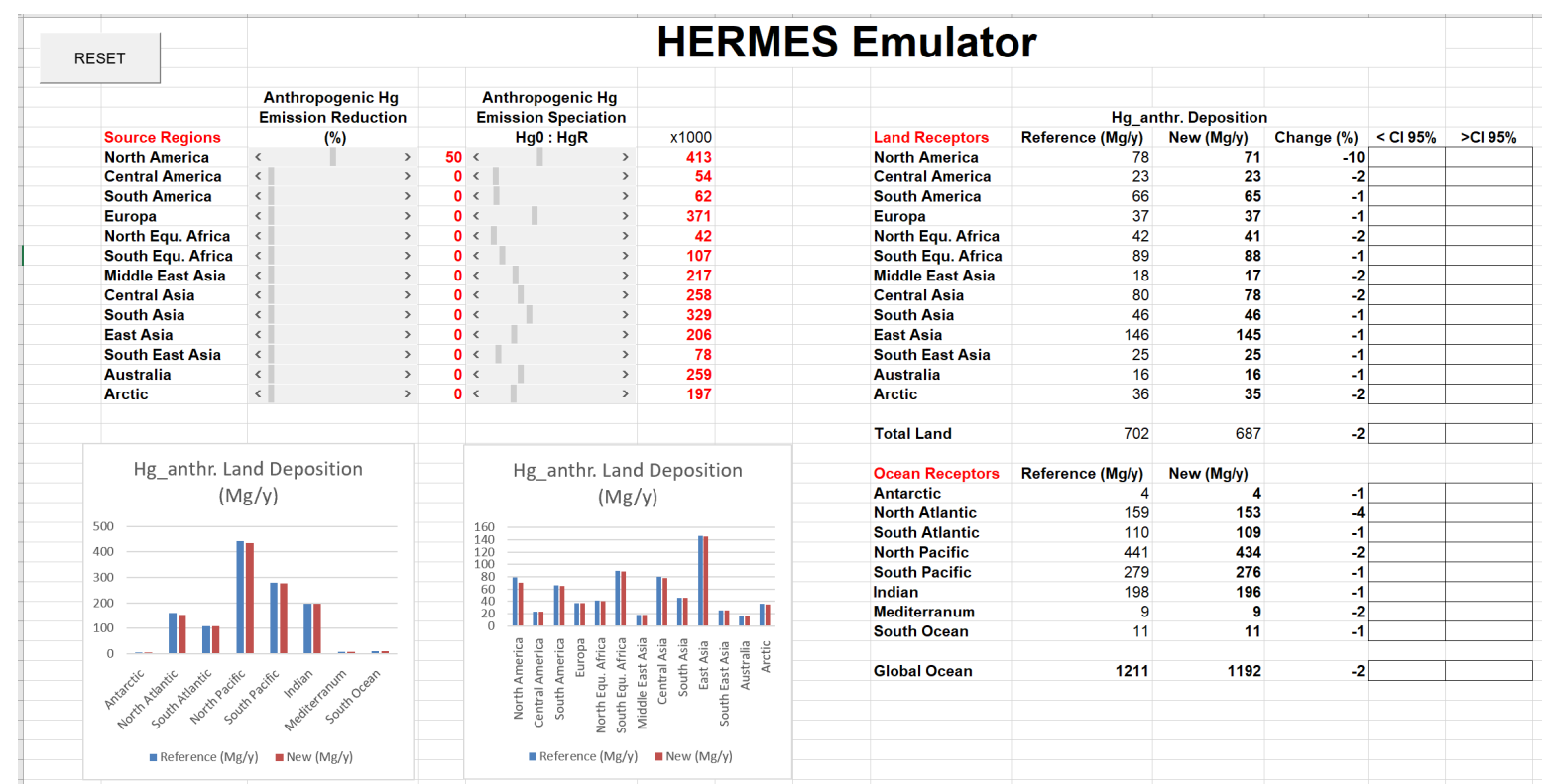

Figure 6. Use-case 4: $\mathrm{Hg}_{\text {anthr }}$ emission reduction by $50 \%$ in North America.

\subsection{Hg Speciation Perturbation}

Changes in $\mathrm{Hg}_{\text {anthr }}$ emission abatement strategies were tested by modifying the $\mathrm{Hg}_{(\mathrm{g})}^{0}: \mathrm{Hg}^{\mathrm{R}}$ ratio. Perturbation of this ratio does not affect the amount of $\mathrm{Hg}_{\text {anthr }}$ deposition on a global scale but only impacts its distribution, which may be of policy interest on a regional scale. For this case, we tested two contrasting scenarios: $\mathrm{Hg}_{(\mathrm{g})}^{0}=0$ and $\mathrm{Hg}^{\mathrm{R}}=100$; and $\mathrm{Hg}_{(\mathrm{g})}^{0}=100$ and $\mathrm{Hg}^{\mathrm{R}}=0$.

In the first scenario there is a greater fraction of $\mathrm{Hg}_{\text {anthr }}$ reaching the global pool (Figure 7), thereby tending to reduce deposition to the regions that are sources and increasing deposition over ocean basins. However, no single change is statistically significant for any of the receptors. In the second scenario, emissions have a shorter atmospheric residence time, resulting in deposition occurring closer to the emission sources (Figure 8). The distribution of $\mathrm{Hg}_{\text {anthr }}$ deposition among the receptors changes markedly also in this case. It increases over land and decreases over oceans, with the exception of the Mediterranean Sea where the deposition increases by $11 \%$. However, only deposition changes over Europe and South East Asia are statistically significant, with an increase of 19\% and 30\%, respectively. 


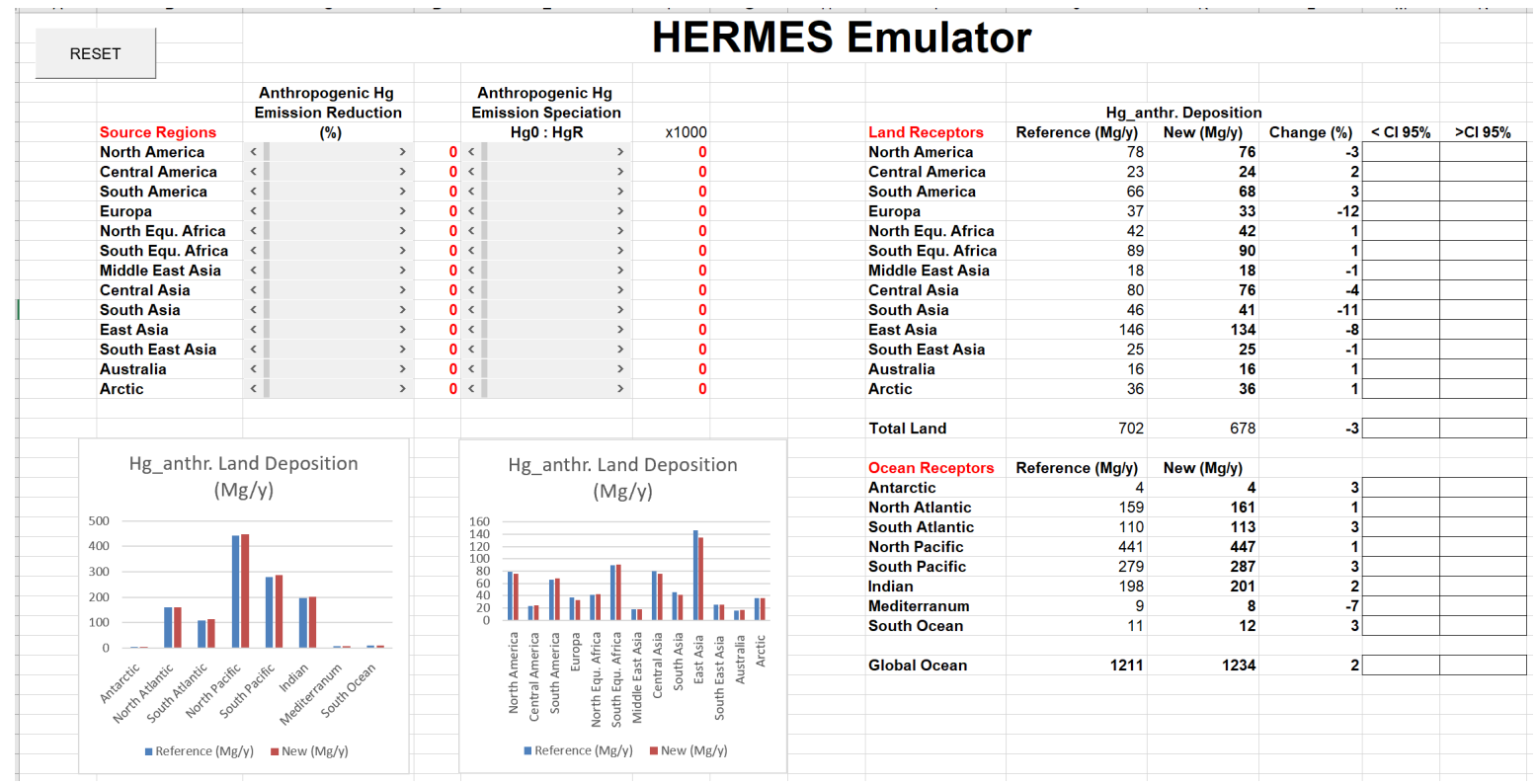

Figure 7. Use-case $5: \mathrm{Hg}_{\text {anthr }}$ fully emitted as $\mathrm{Hg}_{(\mathrm{g})}^{0}$ from all sources.

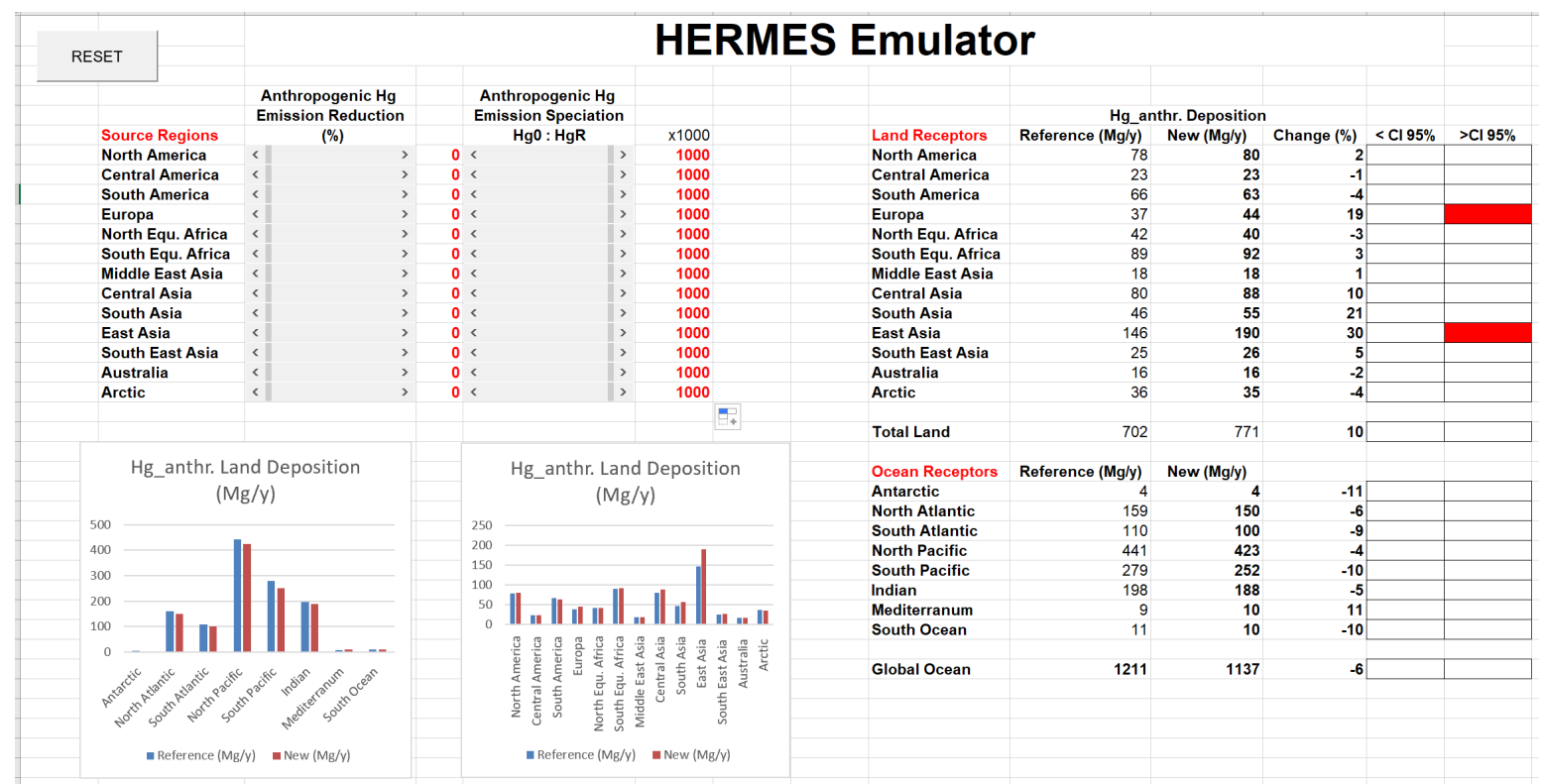

Figure 8. Use-case 6: $\mathrm{Hg}_{\text {anthr }}$ fully emitted as $\mathrm{Hg}^{\mathrm{R}}$ from all sources.

\section{Discussion and Further Development}

In this paper we illustrated the HERMES emulator based on the ECHMERIT Hg-CTM [9-11] aimed to investigate the fate of $\mathrm{Hg}_{\text {anthr }}$ emissions over land and oceans. HERMES captures the essence of the complexity of the $\mathrm{Hg}$ cycle enabling the end-user to obtain interactive and real time results. It provides the full capability of a scientifically robust and validated model, which usually requires advanced scientific formation and technical skills to be used and high-end computing infrastructure to run. We demonstrate how the spreadsheet interface makes the manipulation of $\mathrm{Hg}_{\text {anthr }}$ emissions in each source region user-friendly, providing a tool for policy-makers that can be used to assess short-term effects (nominally one year) of the $\mathrm{Hg}_{\text {anthr }}$ emission perturbation (both reduction and speciation), in real-time and without any specific training or formation.

The linear relationships found for the response of $\mathrm{Hg}_{\text {anthr }}$ deposition to emissions control scenarios (Equations (1) and (2)) are due to the simplification of the inclusion of only $\mathrm{Hg}_{\text {anthr }}$ in the model. 
The inclusion of other natural and legacy Hg emissions in the model is likely to introduce some nonlinearity. Indeed, because of the complexity of the Earth System, and the time scales involved, legacy $\mathrm{Hg}$ re-emissions or exchange of chemical compounds between environmental compartments are not captured by HERMES. However, the $\mathrm{Hg}_{\text {anthr }}$ deposition reduction to a specific ecosystem is an important first step in the reduction of the $\mathrm{Hg}$ burden in that particular ecosystem. In the future developments, a more complete CTM emulator could be built, including all $\mathrm{Hg}$ emission sources, depending on the computational trade-off between the number of emission control scenarios required and the goodness of the fit of the response function. In addition or alternatively, the proposed approach could be integrated with existing tools for the evaluation of long-term abatement strategies, by customising it to a source-receptor version of any biogeochemical cycle model, a number of which have been publicly released (see, for example [36]).

At this development stage, the reduction percentage and the speciation ratio provided for the $\mathrm{Hg}_{\text {anthr }}$ emissions in each source region affects all the emission sectors in that region. It is possible to overcome this simplification by explicitly considering different industrial sectors within each source region. This functionality will require multiple new model runs, but the computational effort would support decision-makers in implementing more precise reduction strategies for each emission sector in a given region. As a forward integration step, these strategies could be associated with their economic and social costs, in such a way the best solution, in terms of both environmental and economic costs, could be assessed.

The confidence intervals provided for $\mathrm{Hg}_{\text {anthr }}$ deposition over receptor regions are calculated starting from the ensemble of runs defined as, "Characterising experiments", as in previous work [4]. Although these runs consider a reasonable range of possible sources of uncertainty, they were designed to assess one source at a time and therefore they do not consider all the plausible combinations of uncertainties. This is due to the computational effort that would be required. Moreover, it should be noted that confidence intervals are calculated based on the current anthropogenic emissions, and therefore the statistical significance of the newly calculated deposition fields are related to the present situation. A more robust statistical comparison between new and present $\mathrm{Hg}$ deposition figures would require the calculation of confidence intervals for each of the runs belonging to "Scenario experiments", (i.e., the combination of runs belonging to the Characterising experiment and the Scenario experiment), and their relative comparison, which would require at least one order of magnitude more CTM runs. Although shortcomings exist, we believe that the comparison of the $\mathrm{Hg}_{\text {anthr }}$ deposition simulated by HERMES for a given scenario with the $\mathrm{Hg}_{\text {anthr }}$ deposition confidence intervals calculated considering the present situation is a reasonable starting point to try to establish an operational calculation of the statistical significance associated with any given policy measures to be adopted.

However, these shortcomings will be addressed in the future versions of HERMES, which are currently under development, that could be distributed on the Web, to further engage the user experience and to provide mechanically readable services in order to improve different user scenarios and interoperability between systems. The web portal of the next version of HERMES could be composed of several widgets with interactive graphs and data tables to provide improved data visualisation. In this way, HERMES would be able to reach multiple users and used more effectively, utilising the same tool, the web, to which stakeholders are accustomed.

\section{Conclusions}

In this study we presented HERMES, a statistical emulator built on the output of a Chemical Transport Model (CTM) for $\mathrm{Hg}$ (ECHMERIT), to simulate changes in $\mathrm{Hg}_{\text {anthr }}$ deposition fluxes due to perturbations to $\mathrm{Hg}_{\text {anthr }}$ emissions. The perturbations encompass both speciation and reduction, simulating thus the implementation of different Best Available Technologies. $\mathrm{Hg}_{\text {anthr }}$ deposition fluxes are calculated in a source-receptor framework, enabling the evaluation of the impact any specific $\mathrm{Hg}_{\text {anthr }}$ emission reduction scenario both regionally and globally, and provide the statistical significance 
of the deposition flux changes, as compared with the current situation. HERMES provides the scientific soundness of a full CTM numerical framework in an interactive and user-friendly spreadsheet and does not require specific training or formation for use. HERMES is the core pillar of a more comprehensive, and integrated, decision support system to aid decision-makers in the evaluation of $\mathrm{Hg}_{\text {anthr }}$ emission reduction policies taken under the Minamata Convention.

Author Contributions: Conceptualization, F.D.S., N.P., S.C.; methodology, F.D.S., I.M.H.; software, F.D.S., F.D. and F.M.; resources, F.S., N.P. and S.C.; validation and investigation, F.D.S., F.C., F.M., F.D. and M.B.; supervision, N.P., F.S., I.M.H. and S.C.; funding acquisition, N.P.; writing-original draft preparation, F.D.S., F.C., F.M., F.D. and M.B.; writing-review and editing, F.D.S., N.P., F.S., I.M.H. and S.C. All authors have read and agreed to the published version of the manuscript.

Funding: The Authors would like to acknowledge the contribution received from EU-H2020 projects which includes ERA-PLANET (Grant Agreement: 689443) through the funded project iGOSP and E-Shape (Grant Agreement: 820852).

Conflicts of Interest: The authors declare no conflict of interest.

\section{Abbreviations}

The following abbreviations are used in this manuscript:

$\mathrm{Hg}_{\text {anthr }} \mathrm{Hg}$ emitted from anthropogenic activities

$\mathrm{Hg} \quad \mathrm{Hg}$ circulating within the Earth System; $\mathrm{Hg}$ includes $\mathrm{Hg}_{\text {anthr }}$

MDPI Multidisciplinary Digital Publishing Institute

DOAJ Directory of open access journals

\section{References}

1. Fitzgerald, W.F.; Engstrom, D.R.; Mason, R.P.; Nater, E.A. The case for atmospheric mercury contamination in remote areas. Environ. Sci. Technol. 1998, 32, 1-7. [CrossRef]

2. Selin, H.; Keane, S.E.; Wang, S.; Selin, N.E.; Davis, K.; Bally, D. Linking science and policy to support the implementation of the Minamata Convention on Mercury. Ambio 2018, 47, 198-215. [CrossRef] [PubMed]

3. Selin, N.E. A proposed global metric to aid mercury pollution policy. Science 2018, 360, 607-609. [CrossRef] [PubMed]

4. De Simone, F.; Hedgecock, I.M.; Carbone, F.; Cinnirella, S.; Sprovieri, F.; Pirrone, N. Estimating Uncertainty in Global Mercury Emission Source and Deposition Receptor Relationships. Atmosphere 2017, 8, 236. [CrossRef]

5. Kwon, S.Y.; Selin, N.E. Uncertainties in atmospheric mercury modeling for policy evaluation. Curr. Pollut. Rep. 2016, 2, 103-114. [CrossRef]

6. Gustin, M.S.; Evers, D.C.; Bank, M.S.; Hammerschmidt, C.R.; Pierce, A.; Basu, N.; Blum, J.; Bustamante, P.; Chen, C.; Driscoll, C.T.; et al. Importance of Integration and Implementation of Emerging and Future Mercury Research into the Minamata Convention. Environ. Sci. Technol. 2016, 50, 2767-2770. [CrossRef]

7. Daniel, J.S.; Solomon, S.; Albritton, D.L. On the evaluation of halocarbon radiative forcing and global warming potentials. J. Geophys. Res. Atmos. 1995, 100, 1271-1285. [CrossRef]

8. Giang, A.; Stokes, L.C.; Streets, D.G.; Corbitt, E.S.; Selin, N.E. Impacts of the minamata convention on mercury emissions and global deposition from coal-fired power generation in Asia. Environ. Sci. Technol. 2015, 49, 5326-5335. [CrossRef]

9. De Simone, F.; Cinnirella, S.; Gencarelli, C.N.; Yang, X.; Hedgecock, I.M.; Pirrone, N. Model study of global mercury deposition from biomass burning. Environ. Sci. Technol. 2015, 49, 6712-6721. [CrossRef]

10. De Simone, F.; Gencarelli, C.N.; Hedgecock, I.M.; Pirrone, N. A modeling comparison of mercury deposition from current anthropogenic mercury emission inventories. Environ. Sci. Technol. 2016, 50, 5154-5162. [CrossRef]

11. De Simone, F.; Artaxo, P.; Bencardino, M.; Cinnirella, S.; Carbone, F.; D'Amore, F.; Dommergue, A.; Feng, X.B.; Gencarelli, C.N.; Hedgecock, I.M.; et al. Particulate-phase mercury emissions from biomass burning and impact on resulting deposition: a modelling assessment. Atmos. Chem. Phys. 2017, 17, 1881-1899. [CrossRef] [PubMed] 
12. Lindberg, S.; Bullock, R.; Ebinghaus, R.; Engstrom, D.; Feng, X.; Fitzgerald, W.; Pirrone, N.; Prestbo, E.; Seigneur, C. A synthesis of progress and uncertainties in attributing the sources of mercury in deposition. Ambio 2007, 36, 19-32. [CrossRef]

13. Jung, G.; Hedgecock, I.M.; Pirrone, N. ECHMERIT v1.0-A new global fully coupled mercury-chemistry and transport model. Geosci. Model Dev. 2009, 2, 175-195. [CrossRef]

14. De Simone, F.; Gencarelli, C.; Hedgecock, I.; Pirrone, N. Global atmospheric cycle of mercury: a model study on the impact of oxidation mechanisms. Environ. Sci. Pollut. Res. 2014, 21, 4110-4123. [CrossRef] [PubMed]

15. Holden, P.B.; Edwards, N.R.; Garthwaite, P.H.; Fraedrich, K.; Lunkeit, F.; Kirk, E.; Labriet, M.; Kanudia, A.; Babonneau, F. PLASIM-ENTSem v1.0: A spatio-temporal emulator of future climate change for impacts assessment. Geosci. Model Dev. 2014, 7, 433-451. [CrossRef]

16. Castruccio, S.; McInerney, D.J.; Stein, M.L.; Liu Crouch, F.; Jacob, R.L.; Moyer, E.J. Statistical emulation of climate model projections based on precomputed GCM runs. J. Clim. 2014, 27, 1829-1844. [CrossRef]

17. Xing, J.; Ding, D.; Wang, S.; Zhao, B.; Jang, C.; Wu, W.; Zhang, F.; Zhu, Y.; Hao, J. Quantification of the enhanced effectiveness of $\mathrm{NO} x$ control from simultaneous reductions of $\mathrm{VOC}$ and $\mathrm{NH} 3$ for reducing air pollution in the Beijing-Tianjin-Hebei region, China. Atmos. Chem. Phys. 2018, 18, 7799-7814. [CrossRef]

18. Xing, J.; Zheng, S.; Ding, D.; Kelly, J.T.; Wang, S.; Li, S.; Qin, T.; Ma, M.; Dong, Z.; Jang, C.J.; et al. Deep learning for prediction of the air quality response to emission changes. Environ. Sci. Technol. 2020, 54, 8589-8600. [CrossRef]

19. Beddows, A.V.; Kitwiroon, N.; Williams, M.L.; Beevers, S.D. Emulation and sensitivity analysis of the community multiscale air quality model for a UK Ozone pollution episode. Environ. Sci. Technol. 2017, 51, 6229-6236. [CrossRef]

20. Gustin, M.S.; Bank, M.S.; Bishop, K.; Bowman, K.; Branfireun, B.; Chételat, J.; Eckley, C.S.; Hammerschmidt, C.R.; Lamborg, C.; Lyman, S.; et al. Mercury biogeochemical cycling: A synthesis of recent scientific advances. Sci. Total. Environ. 2020, 737, 139619. [CrossRef]

21. AMAP/UNEP. Technical Background Report for the Global Mercury Assessment 2013; Technical Report; Arctic Monitoring and Assessment Programme: Oslo, Norway; UNEP ChemicalsBranch: Geneva, Switzerland, 2013.

22. Muntean, M.; Janssens-Maenhout, G.; Song, S.; Selin, N.E.; Olivier, J.G.; Guizzardi, D.; Maas, R.; Dentener, F. Trend analysis from 1970 to 2008 and model evaluation of \{EDGARv4\} global gridded anthropogenic mercury emissions. Sci. Total. Environ. 2014, 494-495, 337-350. [CrossRef]

23. Streets, D.G.; Zhang, Q.; Wu, Y. Projections of Global Mercury Emissions in 2050. Environ. Sci. Technol. 2009, 43, 2983-2988. [CrossRef] [PubMed]

24. Corbitt, E.S.; Jacob, D.J.; Holmes, C.D.; Streets, D.G.; Sunderland, E.M. Global source-receptor relationships for mercury deposition under present-day and 2050 emissions scenarios. Environ. Sci. Technol. 2011, 45, 10477-10484. [CrossRef] [PubMed]

25. Climate Data Operators. Max-Plank Institute fur Meteorologie, 2014. Available online: https:/ / code.zmaw. de/projects / cdo (accessed on 23 February 2015).

26. Simpson, D.; Benedictow, A.; Berge, H.; Bergström, R.; Emberson, L.D.; Fagerli, H.; Flechard, C.R.; Hayman, G.D.; Gauss, M.; Jonson, J.E.; et al. The EMEP MSC-W Chemical Transport Model-Technical Description; Copernicus: Göttingen, Germany, 2012.

27. Emmons, L.K.; Walters, S.; Hess, P.G.; Lamarque, J.F.; Pfister, G.G.; Fillmore, D.; Granier, C.; Guenther, A.; Kinnison, D.; Laepple, T.; et al. Description and evaluation of the Model for Ozone and Related chemical Tracers, version 4 (MOZART-4). Geosci. Model Dev. 2010, 3, 43-67. [CrossRef]

28. Hurrell, J.; National Center for Atmospheric Research Staff (Eds.) The Climate Data Guide: Hurrell North Atlantic Oscillation (NAO) Index (Station-Based). 2020. Available online: https:/ / climatedataguide.ucar. edu/climate-data/hurrell-north-atlantic-oscillation-nao-index-station-based (accessed on 24 April 2020).

29. National Center for Atmospheric Research Staff (Ed.) The Climate Data Guide: Multivariate ENSO Index. 2019. Available online: https:/ / climatedataguide.ucar.edu/climate-data/multivariate-enso-index (accessed on 15 July 2019).

30. Hynes, A.J.; Donohoue, D.L.; Goodsite, M.E.; Hedgecock, I.M. Our current understanding of major chemical and physical processes affecting mercury dynamics in the atmosphere and at the air-water/terrestrial interfaces. In Mercury Fate and Transport in the Global Atmosphere: Emissions, Measurements and Models; Pirrone, N., Mason, R.P., Eds.; Springer: New York, NY, USA, 2009; Chapter 14; pp. 427-457. 
31. Subir, M.; Ariya, P.A.; Dastoor, A.P. A review of uncertainties in atmospheric modeling of mercury chemistry I. Uncertainties in existing kinetic parameters-Fundamental limitations and the importance of heterogeneous chemistry. Atmos. Environ. 2011, 45, 5664-5676. [CrossRef]

32. Subir, M.; Ariya, P.A.; Dastoor, A.P. A review of the sources of uncertainties in atmospheric mercury modeling II. Mercury surface and heterogeneous chemistry-A missing link. Atmos. Environ. 2012, 46, 1-10. [CrossRef]

33. Yang, X.; Cox, R.A.; Warwick, N.J.; Pyle, J.A.; Carver, G.D.; O'Connor, F.M.; Savage, N.H. Tropospheric bromine chemistry and its impacts on ozone: A model study. J. Geophys. Res. Atmos. 2005, 110, 1984-2012. [CrossRef]

34. Yang, X.; Pyle, J.A.; Cox, R.A.; Theys, N.; Van Roozendael, M. Snow-sourced bromine and its implications for polar tropospheric ozone. Atmos. Chem. Phys. 2010, 10, 7763-7773. [CrossRef]

35. Mudelsee, M. Climate Time Series Analysis: Classical Statistical and Bootstrap Methods; Springer International Publishing: Geneva, Switzerland, 2014.

36. Selin, N.E. Global change and mercury cycling: Challenges for implementing a global mercury treaty. Environ. Toxicol. Chem. 2014, 33, 1202-1210. [CrossRef]

Sample Availability: The HERMES CTM emulator is provided as a spreadsheet within the Supplementary Information. 